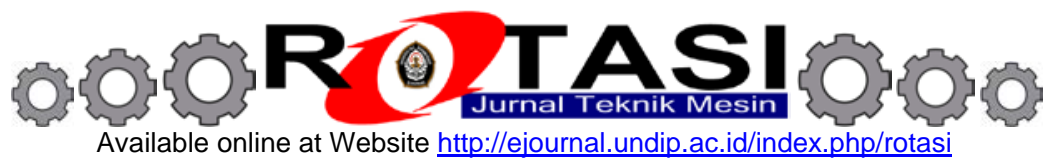

\title{
Estimasi Deformasi Tumit Telapak Kaki Manusia Saat Berdiri Tegak Menggunakan Scanner 3D
}

\author{
Dwi Basuki Wibowo \\ Departemen Teknik Mesin, Fakultas Teknik, Universitas Diponegoro \\ Jl. Prof. Sudharto, SH., Tembalang-Semarang 50275, Telp. +62247460059 \\ Email: ir.dwibasuki.mas@gmail.com
}

\begin{abstract}
Abstrak
Deformasi tumit telapak kaki manusia saat berdiri maupun berjalan sering dikaitkan dengan nyeri di telapak kaki. Besarnya deformasi juga telah diketahui bergantung kepada tingkat ketuaan (aging level), semakin tua manusia semakin kecil deformasinya. Untuk mengukur deformasi tumit tidak mudah dilakukan. Beberapa peneliti sebelumnya menggunakan test rig dan foto rontgen untuk mengetahui heel pad compressibility index (HPCI), apabila nilai HPCI mendekati 1 tumit manusia tergolong sangat kaku. Penelitian ini bertujuan mengestimasi deformasi tumit telapak kaki manusia saat berdiri tegak menggunakan scanner 3D untuk memindai (scanning) telapak kaki tak berbeban dan digital foot scanner untuk memindai telapak kaki berbeban. Dengan Boolean Operation dapat diketahui besarnya deformasi di area tumit tersebut. Dua puluh mahasiswa Departemen Teknik Mesin (DTM) UNDIP dengan usia dan berat badan rata-rata 19.5 tahun dan $55.27 \mathrm{~kg}$ diminta melakukan 2 scanning tersebut. Hasilnya deformasi rata-rata telapak kaki sebesar $7.41 \pm 2.74 \mathrm{~mm}$ dan deformasi maksimum di area tumit rata-rata adalah $13.17 \pm 4.04 \mathrm{~mm}$. Terdapat korelasi yang signifikan antara berat badan $(\mathrm{x}, \mathrm{kg})$ dengan deformasi maksimum di area tumit $(\mathrm{y}, \mathrm{mm})$ subyek penelitian yang dinyatakan oleh persamaan regresi linier $\mathrm{y}=0.276 \mathrm{x}-2.102$ dengan koefisien korelasi $\mathrm{r}=0.85$.
\end{abstract}

Kata kunci: deformasi, tumit, scanner, boolean operation

\section{Pendahuluan}

Telapak kaki merupakan salah satu bagian paling penting dari anggota tubuh yang berinteraksi dengan landasan, baik saat berdiri maupun berjalan. Telapak kaki dan ankle manusia merupakan struktur mekanik yang kuat dan komplek yang terdiri dari 26 tulang, 33 joint (20 diantaranya merupakan joint aktif yang sering digunakan), dan lebih dari seratus otot, tendon, dan ligament. Struktur yang komplek ini menjadikan tubuh seimbang saat berdiri dan berfungsi seperti batang berayun saat berjalan/berlari [1].

Secara umum telapak kaki manusia dibagi menjadi 3 bagian yaitu telapak kaki depan (fore foot), telapak kaki tengah (mid foot), dan telapak kaki belakang (rear foot) atau secara spesifik adalah area metatarsal (termasuk jari-jari kaki), arch, dan heel/calcaneal (tumit) seperti diperlihatkan pada Gambar 1a [2]. Area tumit adalah bagian telapak kaki yang menerima beban paling besar. Saat berdiri area tumit menanggung beban $\pm 60 \%$ berat tubuh (BW : body weight), seperti diperlihatkan pada Gambar 1b [3]. Sedangkan saat berjalan terdapat beban-beban puncak di achilles tendon 3.9 BW, plantar fascia dan plantar ligaments 1.8 BW, serta gaya kontak total yang melintang di sendi-sendi talocalcaneal dan calcaneocuboid masing-masing sebesar $5.4 \mathrm{BW}$ dan 4.2 BW yang seluruhnya memberi kontribusi beban di area tumit [4]. Beban yang besar di area tumit ini sering menimbulkan masalah nyeri di telapak kaki (plantar fasciitis) yang diantaranya disebabkan oleh calcanea/heel spur [5]. Penyakit ini pada keadaan kronik bisa menimbulkan nyeri hebat di tumit sehingga pasien tidak bisa berjalan [6]. Orang gemuk, sering berdiri atau berjalan jauh, dan penderita penyakit gula paling rentan pada penyakit ini [7].

Untuk mengurangi nyeri bisa menggunakan sepatu orthotic yang dirancang khusus yang menghasilkan beban kontak antara sol sepatu dalam (in-sole) dengan area tumit lebih kecil dari gaya tekan minimum nyeri [8-10]. Ini berarti langkah pertama yang harus dilakukan adalah mengetahui besarnya beban di area tumit yang berkaitan dengan besarnya deformasi yang terjadi di area tersebut.

Mengukur deformasi di area tumit saat manusia berdiri tegak tidaklah mudah. Hsu dkk menggunakan test rig alat berbeban-tak berbeban (loading-unloading device) untuk mengukur ketebalan tumit (HPT, heel pad thickness), seperti terlihat pada Gambar 2a [11]. Sebuah ultrasound transducer $7.5 \mathrm{MHz}$ liniear-array yang bisa digeser naik-turun dipasang di A6 yang dihubungkan dengan sebuah push-pull scale di A5. Transduser ultrasound bisa digeser naik turun secara manual dengan memutar kenop di bagian atas dan oleh karena itu HPT dapat diukur secara tepat dari sonogram pada beban yang berbeda yang dikontrol oleh posisi skala tarik-tekan. Nass dkk menggunakan ultrasonogram untuk mengukur HPT sedangkan untuk membangkitkan citra ultrasound-nya digunakan alat hand held $7 \mathrm{MHz}$ sector ultrasound probe (RT 6800 GE Medical Systems) [12]. Untuk mengukur HPT kondisi statik, subyek penelitian diminta duduk dengan 1 kaki di atas platform bertanda scale sedangkan kaki yang lain di atas plexiglass, seperti terlihat pada Gambar 2b. Pembebanan diatur dari 0, 10, 25, 50, 75, dan 100\% dengan cara menekan telapak kaki pada platform yang diukur menggunakan loadcell pada platform bertanda scale. Beban dari 0 s/d 75\% dilakukan dengan cara duduk, sedangkan beban $100 \%$ dilakukan dengan cara subyek berdiri di atas platform. Ketebalan tumit yang diukur di sini 
adalah antara kulit hingga calcaneal tuberosity. Cara lain adalah menggunakan foto rontgen (lateral x-ray) seperti yang dilakukan oleh Prichasuk [13]. ULHPT adalah jarak dari garis kulit tanpa beban (YU) ke garis plantar tuberosity of the calcaneum (YO), sedangkan LHPT adalah jarak dari garis kulit berbeban (YL) ke YO (Gambar 3). Baik ULHPT maupun LHPT diukur berdasarkan hasil lateral $x$-ray dari area kulit sampai tulang. Besarnya deformasi tumit akibat berat sendiri dapat diketahui dari jarak YU ke YL.

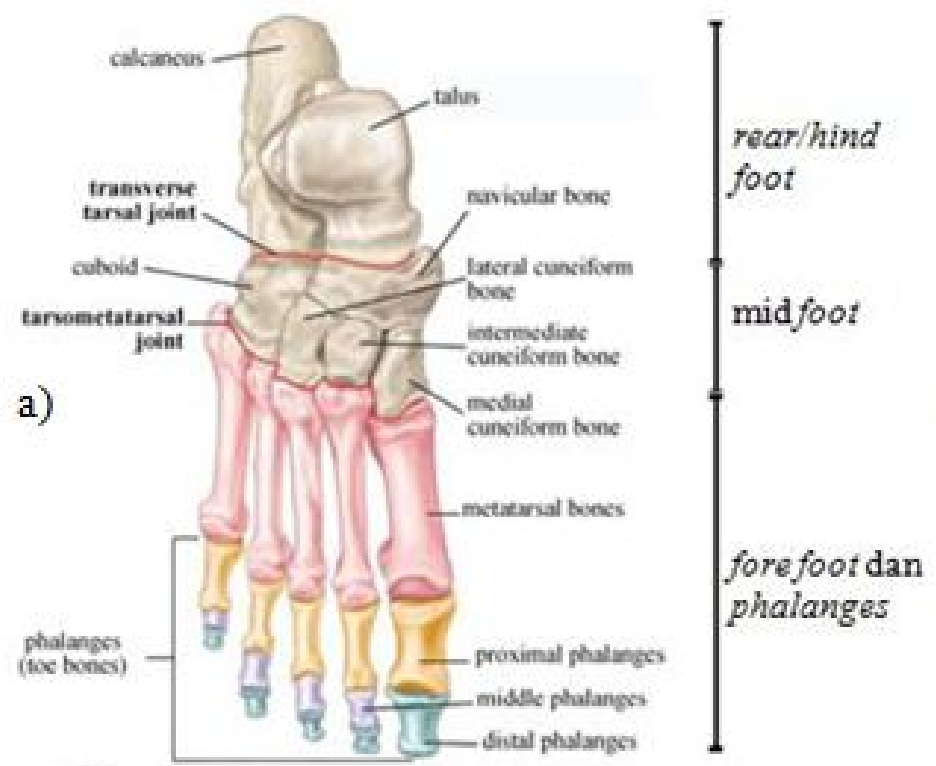

b)

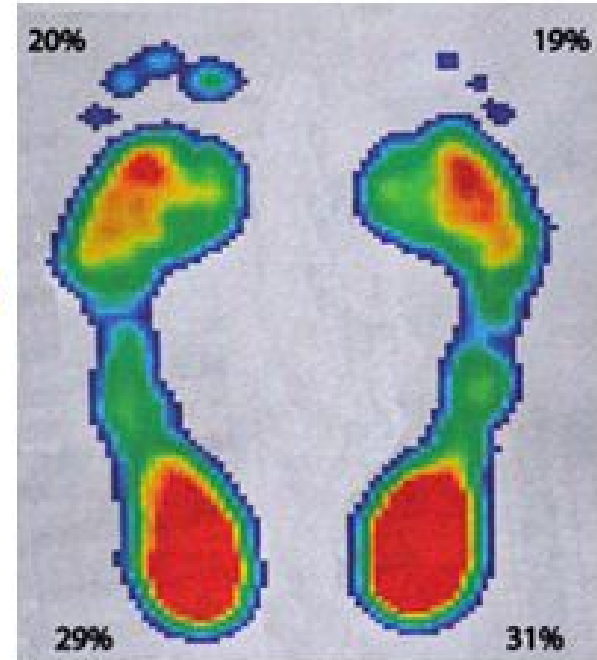

Gambar 1. a) pembagian telapak kaki dan b) distribusi beban di telapak kaki

Penelitian ini bertujuan mengestimasi deformasi tumit akibat berat sendiri yang diperoleh dari kedalaman jejak telapak kaki (footprint depth) hasil perpotongan area tumit tak berbeban dengan berbeban yang disebut dengan Boolean Operation. Penelitian ini merupakan hal baru karena baik telapak kaki tak berbeban maupun berbeban keduanya diperoleh dari 3D scanning dan digital foot scanning.

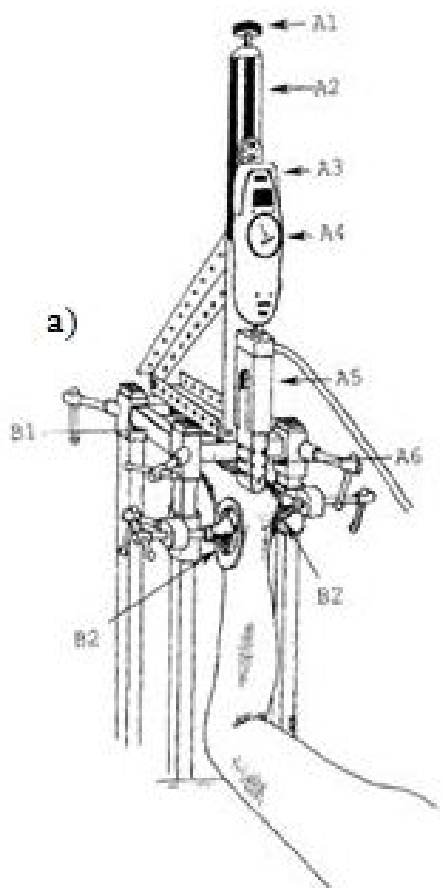

b)
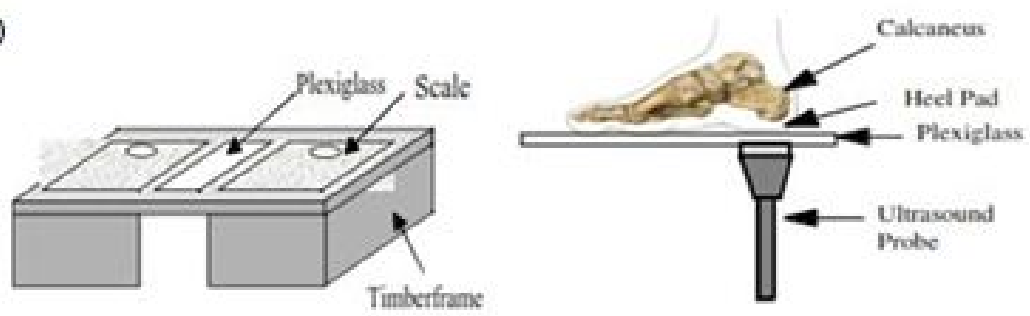

Gambar 2. Mengukur ketebalan tumit yang dilakukan oleh a) Hsu dkk dan b) Nass dkk 


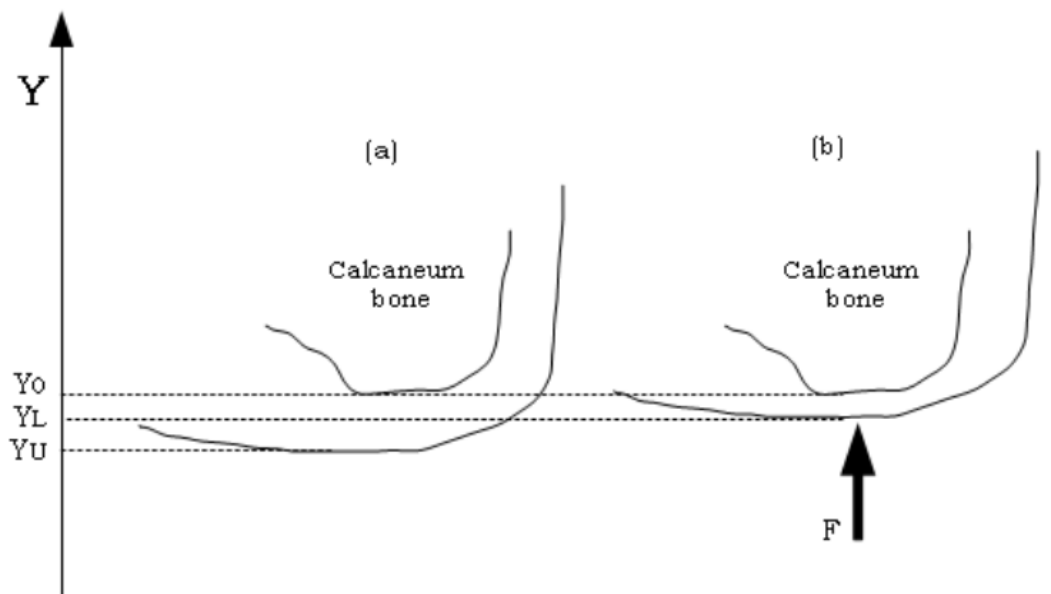

Gambar 3. Ilustrasi skematik unloaded (a) dan loaded (b) tumit akibat berat sendiri

\section{Metode penelitian}

Dua puluh mahasiswa Departemen Teknik Mesin (DTM) UNDIP dengan karakteristik seperti diperlihatkan pada Tabel 1 direkrut sebagai subyek penelitian. Mereka diminta untuk melakukan scanning telapak kaki berbeban dan berbeban. Scanning telapak kaki berbeban dilakukan menggunakan 3D scan for foot orthotic (ScanPod 3D, Vismach Technology Ltd., Hong Kong, China), seperti diperlihatkan pada Gambar 4a. Hasil scan dalam bentuk plantar view diperlihatkan pada Gambar 4b. Untuk memperoleh koordinat telapak kaki dilakukan dengan cara mengimport file .dxf hasil 3D scanning menggunakan AutoCAD dan membuka Microsoft Excel yang tersedia di AutoCAD. Hasil pengeplotan titik-titik koordinat telapak kaki diperlihatkan seperti Gambar 4c [14] dan dengan menggunakan MATLAB dapat diperoleh fungsi $\mathrm{f}(\mathrm{x}, \mathrm{y})$ seperti terlihat pada Gambar 5 [15].

Scanning telapak kaki tak berbeban dilakukan menggunakan digital foot scanner yang dibuat sendiri hasil modifikasi flatbed document scanner ukuran A4 dan dirancang untuk men-scan satu telapak kaki secara bergantian, seperti terlihat pada Gambar 6a. Proses scanning dilakukan setelah subyek berdiri tegak di atas platform dan hasil scanning-nya diperlihatkan pada Gambar 6b. Untuk memperoleh citra footprint, bagian telapak kaki yang tidak berkontak dengan platform harus dihilangkan menggunakan MATLAB (Gambar 6c). Dari footprint ini dapat ditentukan foot area contact (FAC), foot width (FW) dan foot length (FL) dengan menggunakan MATLAB.

Tabel 1. Karakteristik subyek penelitian

\begin{tabular}{|l|c|c|}
\hline & Rentang nilai & Rata2 dan Standar Deviasi \\
\hline Umur (tahun) & $18-23$ & $19.5 \pm 1.28$ \\
\hline Jenis kelamin (laki2 : perempuan) & & $10: 10$ \\
\hline Berat badan $(\mathrm{kg})$ & $39-88$ & $55.27 \pm 12.45$ \\
\hline Tinggi badan $(\mathrm{cm})$ & $147.8-174.0$ & $159.51 \pm 8.03$ \\
\hline BMI $\left(\mathrm{kg} / \mathrm{m}^{2}\right)$ & $16.23-31.99$ & $21.67 \pm 4.18$ \\
\hline
\end{tabular}

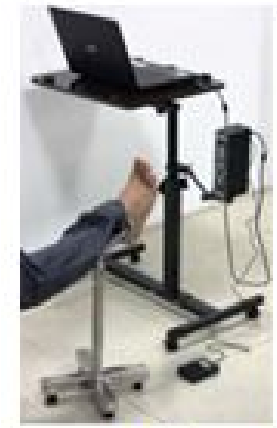

(a)

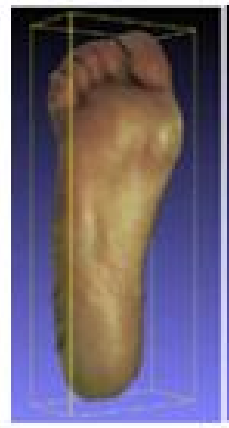

(b)

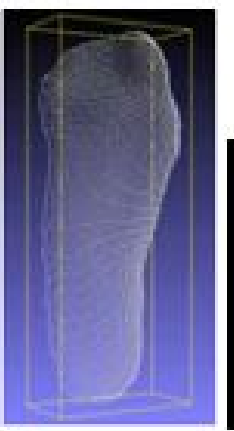

Gambar 4. Hasil 3D scanning telapak kaki

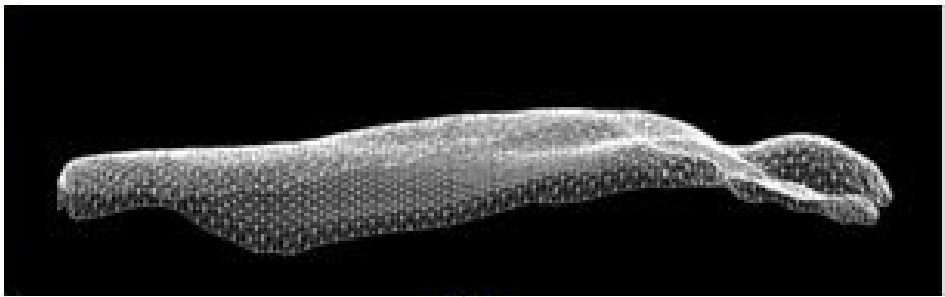

(c) 


$$
\begin{aligned}
f(x, y) & =-6.6460 e^{-4}+1.6576 x+0.5137 y-0.0418 x^{2}+0.0159 x y-0.0226 y^{2} \\
& +6.2576 e^{-4} x^{3}-5.9905 e^{-4} x^{2} y-7.0945 e^{-5} x y^{2}+2.7086 e^{-4} y^{3}-6.8237 e^{-6} x^{4} \\
& +7.3267 e^{-6} x^{3} y+4.5563 e^{-6} x^{2} y^{2}-9.8523 e^{-7} x y^{3}-1.1667 e^{-6} y^{4}+3.3499 e^{-8} x^{5} \\
& -4.5741 e^{-8} x^{4} y-8.1361 e^{-9} x^{3} y^{2}-1.1965 e^{-8} x^{2} y^{3}+4.4396 e^{-9} x y^{4}+1.6265 e^{-9} y^{5}
\end{aligned}
$$

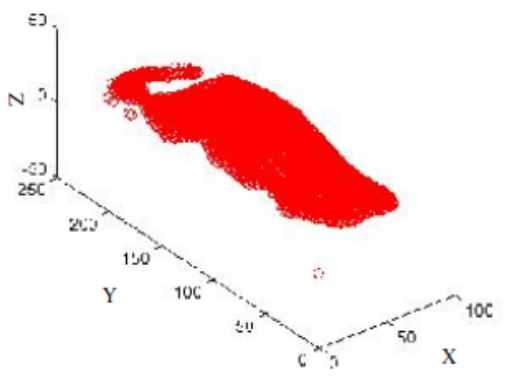

Gambar 5. Fungsi polynomial kontur telapak kaki salah satu subyek penelitian

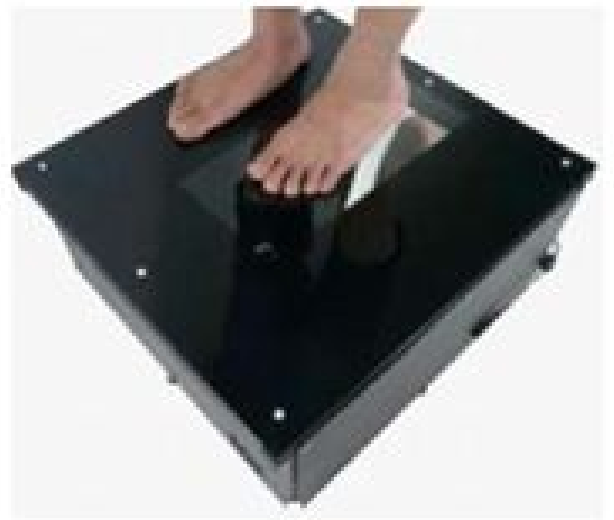

(a)

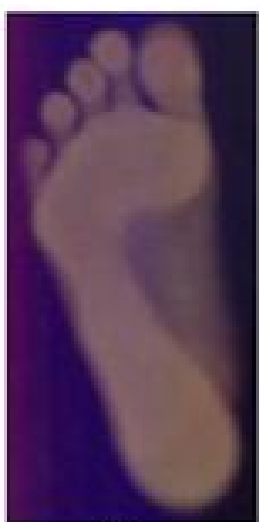

(b)

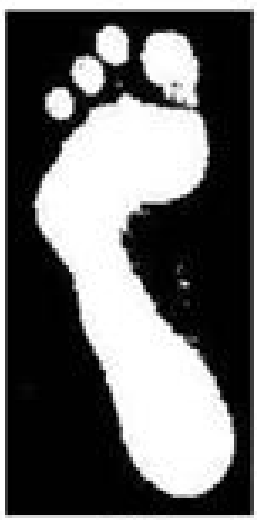

(c)

Gambar 6. Hasil scanning telapak kaki berbeban menggunakan digital foot scanner

Untuk memperoleh footprint depth di daerah tumit hasil perpotongan antara scan telapak kaki tak berbeban dengan berbeban harus ditentukan terlebih dahulu daerah tumit yang dimaksud. Pada penelitian ini daerah tumit adalah rear foot yang berjarak (vertikal) 31\% FL diukur dari ujung tumit, seperti nampak pada Gambar 7 [16], sedangkan FL adalah jarak terjauh dari ujung tumit hingga jari kaki. Prosedur perpotongan ke dua hasil scan tersebut dilakukan dengan MATLAB yang terdiri dari 2 bagian yaitu: mendeteksi sisi-sisi citra footprint berwarna putih (Gambar 6c) menggunakan fungsi bwboundaries dan baca koordinat 3D scanner dengan membuka data MSExcel menggunakan fungsi xlsread atau menggunakan fungsi polinomial telapak kaki seperti pada Gambar 5. Setelah itu skalakan batasbatas luar area telapak kaki dengan batas-batas koordinat yang diperoleh dari 3D scanner menggunakan rasio nilai maksimum dan minimum nilai ordinat-y dan sesuaikan dengan posisi area luar telapak kaki, posisi area dalam telapak kaki, dan koordinat yang diperoleh dari 3D scanner sedemikian sehingga berada dalam satu baris. Besarnya footprint depth atau deformasi di area tumit selanjutnya dapat ditentukan dari “matching” nilai koordinat x dan y dari 3D scanner dengan batas-batas area dalam telapak kaki dan menghilangkan area luar dari batas-batas area dalam telapak kaki. Gambar 8 memperlihatkan hasil Boolean Operation 3D foot dengan citra footprint menggunakan MATLAB.

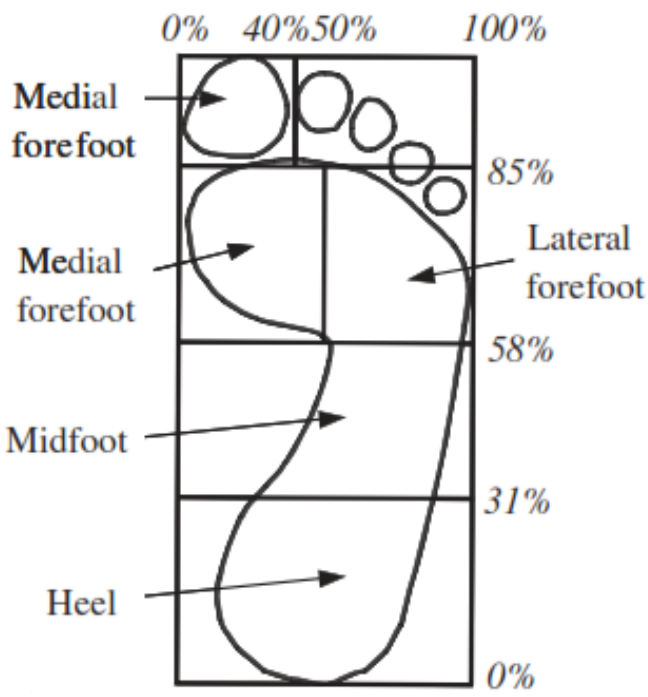

Gambar 7. Definisi daerah tumit (heel region) 

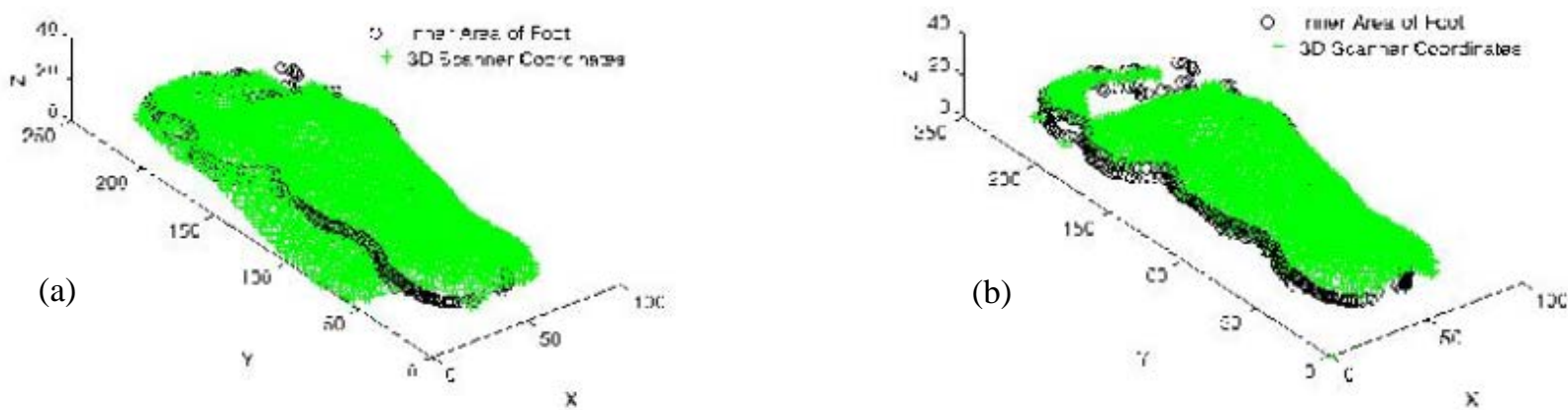

Gambar 8. Boolean operation antara citra 3D foot dengan footprint, a) perpotongan citra 3D foot dengan footprint, b) kontur footprint depth hasil perpotongan

Footprint depth maksimum di seluruh area telapak kaki dapat ditentukan menggunakan fungsi polinomial yang telah di-generate dari MSExcel (Gambar 9), dimana Gambar 9a memperlihatkan tempat kedudukan titik-titik lokasi footprint depth maksimum di telapak kaki pada pandangan plantar dan Gambar 9b memperlihatkan perbandingan footprint depth maksimum dari fungsi polinomial dengan sorting maksimum koordinat-z dari 3D scanner pada pandangan longitudinal.

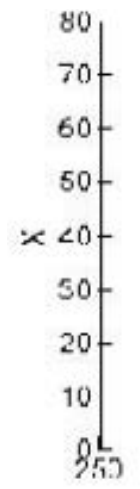

$\sim 50$
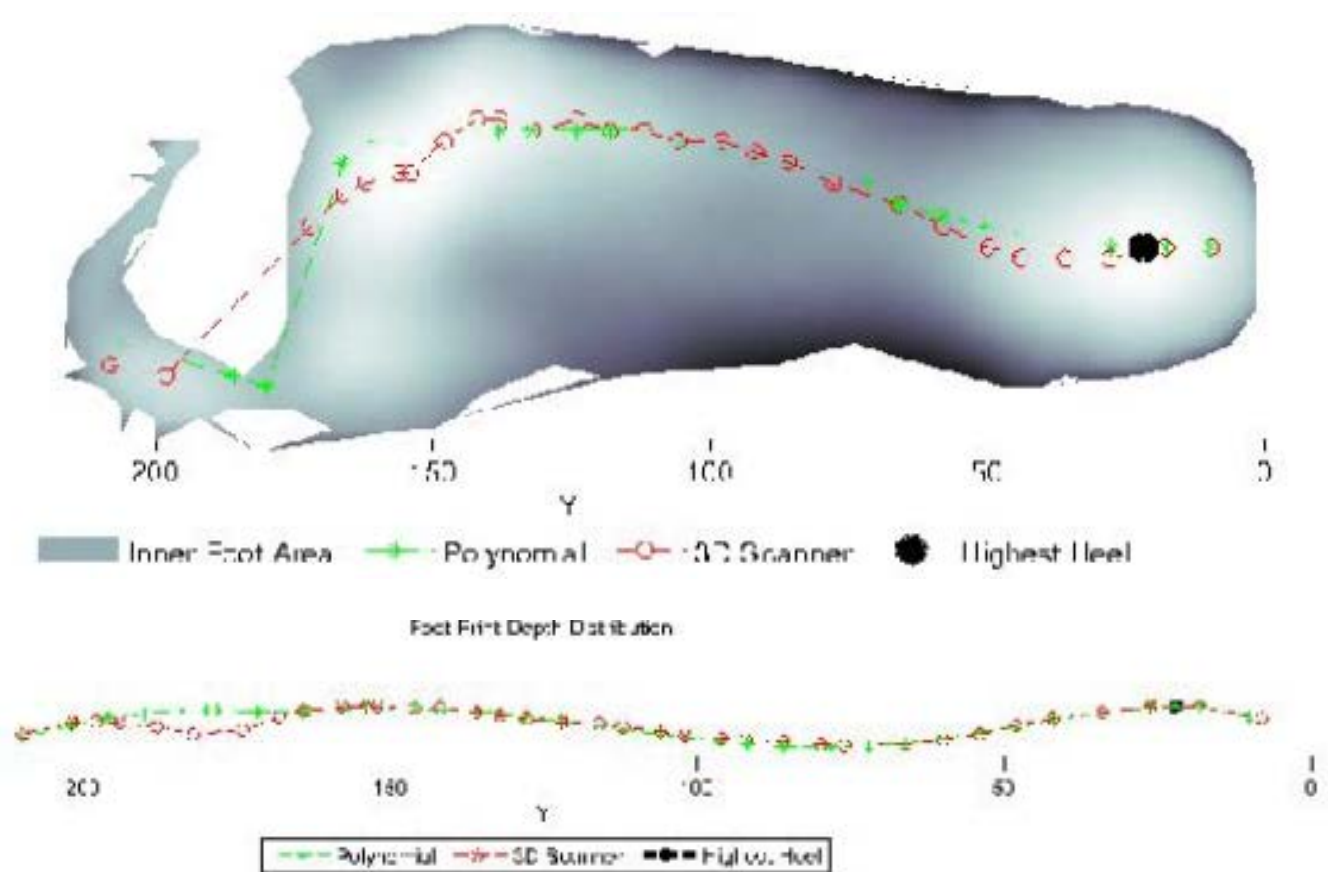

Gambar 9. Footprint depth maksimum telapak kaki salah satu subyek penelitian

\section{Hasil penelitian dan diskusi}

Rata-rata berat badan subyek laki-laki lebih besar daripada subyek perempuan. Rata-rata berat badan laki-laki adalah $60.49 \pm 2.93 \mathrm{~kg}$ sedangkan perempuan $50.05 \pm 7.93 \mathrm{~kg}$ [17].

Dari hasil pengukuran pada 20 subyek penelitian menunjukkan terdapat korelasi signifikan antara berat badan dengan deformasi maksimum rata-rata di seluruh area telapak kaki, yang dapat dinyatakan dalam bentuk fungsi regresi linier $\mathrm{y}=0.178 \mathrm{x}-2.47$ dimana $\mathrm{x}$ dan $\mathrm{y}$ masing-masing menyatakan berat badan $(\mathrm{kg})$ dan deformasi telapak kaki maksimum (mm) seperti nampak pada Gambar 10. Besarnya deformasi maksimum rata-rata adalah $7.41 \pm 2.74 \mathrm{~mm}$ dan koefisien korelasi ke duanya adalah 0.81 . Hasil korelasi ini menunjukkan semakin tinggi berat badan, semakin besar deformasi di telapak kaki [18].

Terdapat korelasi signifikan antara berat badan dengan deformasi maksimum rata-rata di area tumit, yang dapat dinyatakan dalam bentuk fungsi regresi linier $\mathrm{y}=0.276 \mathrm{x}-2.102$ dimana $\mathrm{x}$ dan $\mathrm{y}$ masing-masing menyatakan berat badan $(\mathrm{kg})$ dan deformasi tumit maksimum $(\mathrm{mm})$ seperti nampak pada Gambar 11. Besarnya deformasi maksimum rata-rata adalah $13.17 \pm 4.04 \mathrm{~mm}$ dan koefisien korelasi ke duanya adalah 0.85. Hasil korelasi ini menunjukkan semakin tinggi berat badan, semakin besar deformasi di area tumit [19-20]. 


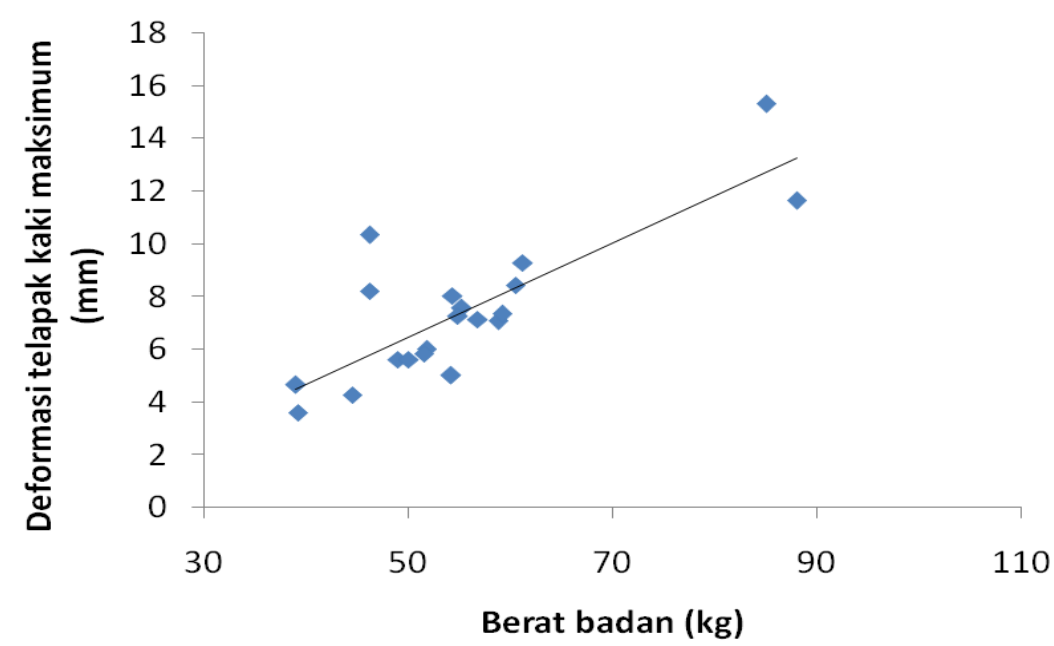

Gambar 10. Korelasi antara berat badan dengan deformasi rata-rata di telapak kaki maksimum

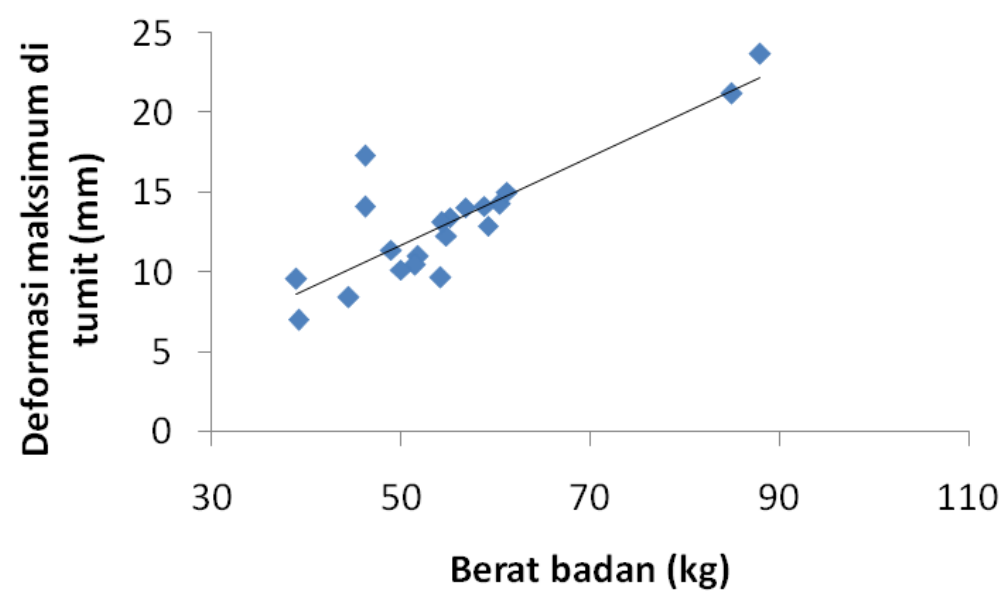

Gambar 11. Korelasi antara berat badan dengan deformasi rata-rata di tumit maksimum

Deformasi maksimum di telapak kaki dan di tumit pada subyek berjenis kelamin laki-laki lebih besar dibandingkan perempuan [21]. Deformasi maksimum di telapak kaki rata-rata untuk jenis kelamin laki-laki adalah $8.36 \pm 2.93 \mathrm{~mm}$ dan untuk perempuan adalah $6.46 \pm 2.30 \mathrm{~mm}$. Sedangkan deformasi maksimum di tumit rata-rata untuk jenis kelamin laki-laki adalah $14.67 \pm 4.34 \mathrm{~mm}$ dan untuk perempuan adalah $11.67 \pm 3.25 \mathrm{~mm}$.

\section{Kesimpulan}

Deformasi di area tumit lebih besar daripada deformasi rata-rata di telapak kaki saat manusia berdiri tegak di atas landasan rata. Baik deformasi di telapak kaki maupun di area tumit pada subyek berjenis kelamin laki-laki lebih besar dibandingkan perempuan. 3D scanning terbukti dapat menghasilkan fungsi kontur telapak kaki yang bermanfaat untuk mengektraksi nilai koordinat z di seluruh area telapak kaki dan tumit. Dengan fungsi kontur tersebut mudah dilakukan Boolean Operation antara kontur hasil 3D scan dengan footprint hasil digital foot scanner di area tumit untuk mencari deformasi (footprint depth) tumit akibat berat sendiri.

\section{Daftar pustaka}

[1] Klenerman L, Wood B., 2006, “The Human Foot: A Companion to Medical Studies”, Berlin, Springer.

[2] P.R. Cavanagh and M.M. Rodgers, J. Biomechanics 20(5), 547-551(1987)

[3] Jason KK Chia, Sanjay Suresh, Angeline Kuah, Jean LJ Ong, Jessie MT Phua, Ai Ling Seah. Comparative Trial of The Foot Pressure Patterns Between Corrective Orthotics, Formthotics, Bone Spur and Flat Insoles in Patients with Chronic Plantar Fasciitis. Ann Acad Med Singapore, 2009; 38: 869 - 75

[4] Virginia L. Giddings, Gary S. Beaupre, Robert T. Whalen, and Dennis R. Carter. Calcaneal Loading During Walking and Running. Medicine \& Science in Sport \& Exercise, American College of Sports Medicine, 2000

[5] Stephen L. Barrett and Robert O’Malley. Plantar Faciitis and Other Causes of Heel Pain. Am Fam Physician. 1999 Apr 15;59(8): 2200 - 2206

[6] Bergmann J. N., 1990. History and Mechanical Control of Heel Spur Pain. Clin. Podiatr. Med. Surg. 1990 Apr; $7(2): 243-59$ 
[7] J. Bartold Simon. The Plantar Fascia as a Source of Pain - Biomechanics, Presentation and Treatment. Journal of Bodywork and Movement Therapies, Elsevier, 2004

[8] Mika Shimizu and Paul D. Andrew. Effect of heel height on the foot in unilateral standing. J. Phys. Ther. Sci. 11: 95-100, 1999

[9] Jia Xiaohong, Wang Rencheng and Winson Lee. Effects of shoe heel height on loading and muscle activity for trans-tibial amputees during standing. Tsinghua Science and Technology. ISSN 1007-0214 01/18 pp 281-286, Volume 14, Number 3, June 2009

[10] Yan Cong, Jason Tak-Man Cheung, Aaron KL Leung, and Ming Zhang. Effect of heel height on in-shoe localized triaxial stresses. Journal of Biomechanics 44 (2011) 2267-2272

[11] Tsz-Ching Hsu, Chung-Li, Wen-Chung Tsai, et al. Comparison of the mechanical properties of the heel pad between young and elderly adults. Arch Phys Med Rehabil Vol 79, September 1998

[12] D. Nass, Hennig and V. Treek, The Thickness of the Heel Pad Loaded by Bodyweight in Obese and Normal Weight Adults, Biomechanics Laboratory, University of Essen, Germany, D 45117 (2000)

[13] Somchai Prichasuk, Pornchai Mulpruek and Pimjai Siriwongpairat. The heel pad compressibility. Clinical Orthopaedics and Related Research, Vol. 300, pp. 197-200, 1994

[14] Dwi Basuki Wibowo, Gunawan Dwi Haryadi, and Agus Priambodo. Estimation of Foot Pressure from Human Footprint Depths Using 3D Scanner. AIP Conference Proceedings, ISBN: 978-0-7354-1365-8, Vol. 1717, (2016). doi: 10.1063/1.4943451

[15] Dwi Basuki Wibowo, Gunawan Dwi Haryadi, Achmad Widodo, Sri Puji Rahayu. Estimation of calcaneal loading during standing from human footprint depths using 3D scanner. AIP Conf. Proc. 1788, 030063-1-030063-9; doi: 10.1063/1.4968316

[16] Yung-Hui, Lee, et al, 2005, "Effects of shoe inserts and heel height on foot pressure, impact force, and perceived comfort during walking”, Applied Ergonomics 36 (2005) 335-362, Elsevier

[17] Roshna E. Wunderlich and Peter R. Cavnagh, 2001. Gender differences in adult foot shape: Implications for shoe design. Med. Sci. Sports Exer., 33: 605-611

[18] Asanka S. Rodrigo, Ravindra S. Goonetilleke and Shuping Xiong (2013). Load distribution to minimize pressurerelated pain on foot: a model. Ergonomics, 56:7, 1180-1193, DOI: 10.1080/00140139.2013.797111

[19] Kinoshita H., Francio P.R., Murase T., et al. The mechanical properties of the heel pad in elderly adults. European Journal of Applied Physiology. Vol. 73, pp. 404-409, 1996.

[20] Somchai Prichasuk. The heel pad in plantar heel pain. J Bone Joint Surg [Br] 1994; 76-B: 140-2

[21] R. Periyasamy, A. Mishra, Sneh Anand, et al. Preliminary investigation of foot pressure distribution variation in men and women adults while standing. The Foot 21 (2011) 142-148 